\title{
Grundtvig om danskhed og modersmål i 1839 En tale 5. november 1839
}

Ved Flemming Lundgreen-Nielsen

\section{Indledning}

1838 var halvtredsårsjubilæet for Stavnsbåndets løsning. I den anledning holdt Grundtvig som privatmand fra 20. juni til 26. november offentlige forelæsninger over disse 50 år af Europas historie, Danmarks medregnet. De foregik i auditoriet på Borchs kollegium i St. Kannikestræde 12 og blev et sandt tilløbsstykke. Det betød et afgørende gennembrud både for Grundtvigs personlighed og for hans ideer hos de unge københavnske akademikere. Fra nu af kunne han for alvor mærke medvind i offentligheden, endda i stadig tiltagende grad. Foredragene blev i $\emptyset$ vrigt udgivet i 1877 af sønnen Svend under titlen Mands Minde 1788-1838.

Nogle deltagere herfra opsøgte 2. april 1839 Grundtvig og bad ham danne et levende folkeligt selskab til fremme af danskhed. Primus motor var den 28-årige student Frederik Barfod, blandt de andre var Fr. Hammerich, P.C. Kierkegaard (broder til Søren) og Orla Lehmann. Grundtvig overlod det til Barfod at skaffe et egnet lokale og holdt derpå tre prøveforedrag 18., 23. og 30. april. Det forløb godt, så efter endnu et møde 7. maj enedes man 14. maj om at stifte en forening. Den endte med at hedde Danske Samfund, trods mange forskellige andre forslag til navn fra Grundtvig. Han var formand frem til 1843 og igen i 1848.

Danske Samfunds historie er beskrevet kortfattet af Grundtvig selv i Fr. Barfods tidsskrift Brage og Idun, et nordisk Fjardingårsskrift, I:2, 1839, s. 414-473. Fakta om foreningen er samlet af Steen Johansen i Bibliografi over N.F.S. Grundtvigs Skrifter, II, 1950, s. 137-138, og i Grundtvig-Studier 1955, s. 91-93. Den mest omfattende unders $ø$ gelse er, med adskillige citater af utrykt materiale samt en udførlig bibliografisk oversigt, foretaget af nærværende udgiver i Dansk Identitetshistorie, III, 1992, s. 31-79, hvortil der generelt henvises. 
Under Mands Minde-foredragene havde mangelen på vekselvirkning med tilhørerne ærgret Grundtvig. Danske Samfund blev derfor indrettet som en forening, hvor samtalen - efter et kort, på forhånd forberedt oplæg - skulle være hovedsagen.

Grundtvig skrev over hundrede sådanne oplæg, som i dag ligger i Grundtvig-arkivets fasc. 364.I-II, med en afskrift af Svend Grundtvig i fasc. 365. Afskriften, der ikke medtager alternative versioner eller overstregede passager, må forstås som manuskript til en beklageligt nok aldrig realiseret udgave.

To principielle indledninger og fire oplæg lod Grundtvig selv trykke i nævnte nummer af Brage og Idun; 28. maj-talerne 183940 kom i H.K.Rasks Morskabslaesning for Den Danske Almue. Elleve oplæg udsendte Grundtvig i pjeceform. Endelig optoges otte oplæg i Grundtvigs tidsskrift Danskeren, årgang 1848 og 1851. Der er dog ikke bevaret manuskripter til samtlige disse tryk. I moderne tid er hidtil kun en tale fra 4. maj 1841 udgivet ved Steen Johansen i Grundtvig-Studier 1955, s. 86-91. Flertallet af manuskripterne - ca. 80 - er således stadig utrykt.

Talerne, der næsten alle er autodaterede, er affattet til det enkelte møde, efter udseendet at dømme undertiden i stor hast. De fleste er ganske korte - fire sider. Mange slutter vilkårligt uden afrunding af tankegangen. Det betyder antagelig, at Grundtvig har skrevet dem og haft dem med til mødet som en sikkerhed for, at han ville kunne tale sig varm. Han har så improviseret videre fra, hvor teksten slap op. Nogle hidtil ukendte anonyme politireferater fra møderne rummer $i$ hvert fald enkeltheder, oplæggene ikke har. Desværre har Grundtvig i almindelighed ikke efter mødet skrevet videre på teksten eller indarbejdet tilhørernes reaktioner.

Talen fra 5. november 1839 handler om Grundtvigs forhold til det danske sprog og det begreb om danskhed, han afleder deraf. Den er overleveret med to begyndelser. Det kan næppe med sikkerhed afgøres, hvilken der er ældst. Steen Johansen mener i Grundtvig-registranten uden argumentation, at den korte enhed 17 er et første udkast til enhed 16. Begge tager udgangspunkt i, at Grundtvig samme dag som censor ved teologisk embedseksamen har hørt dårligt dansk og slet latin. Det er i $\emptyset v r i g t$ her et problem, at Grundtvig ifølge universitetets censorprotokol netop 5. november 1839 var udeblevet uden af- 
bud. K.E. Bugge har foreslået, at man kan have hentet ham, da man konstaterede hans fravær (se her note 1).

Det korte udkast bevæger sig hurtigt videre til en holsteners frimodigt forkerte påstande om højtysk sprogs stilling i Danmark og opgives så. Først efter Frederik 6.s død en måned senere skærpedes for alvor de sproglige og nationale modsætninger mellem dansk og tysk inden for helstaten.

Den lange tekst - vel den anvendte - holder sig til det rent danske. Den kortlægger, hvorledes Grundtvig, imod alle odds, ved krydstogter mellem en række andre sprog endte i modersmålets favn. Den moderne forsknings nærlæsninger i Grundtvigs manuskripter rokker ved nogle af dateringerne, så de er nok foretaget efter hukommelsen.

I sin længste form indgår oplægget i rækken af Grundtvigs selvfortolkende, let upræcise beretninger om sin egen åndelige udvikling. Han giver en både klar og kærlig redegørelse for sit personlige forhold til modersmålet. Han føler sig nemlig nu så gammel, at han kan behandle koldt, hvad han glødende føler, og spøge med, hvad der er hans alvor.

Teksten må ellers tale for sig selv. Man bemærker, at Grundtvig i en alder af 56 år føler sig ældet og på retur. Og oplysningen om, at herskabet på Egeløkke talte flydende tysk til daglig, er vist ny.

\section{Udgivelsen}

Manuskriptet, som er skrevet på hvidt papir uden vandmærke, måler 22,5 x $18 \mathrm{~cm}$. Enhed 16 består af to læg, hver mærket med tre prikker øverst til venstre på forsiden. Enhed 17 består af et enkeltblad med samme afmærkning på forsiden. Disse prikker er Grundtvigs forkortelse for I.J.N., dvs. i Jesu Navn, en rutinemæssig indvielse af hvert læg.

Teksten gengives bogstav- og tegnret. De mange sproglige smårettelser - i alt 66 - er ikke aftrykt eller markeret. En enkelt overstreget sætning, som skønnes af betydning for indholdet, er medtaget i note 9. Udgiverens få rettelser af skrive- og sjuskefejl er ligeledes meddelt i noter. Et enkelt udeladt anførelsestegn samt et manglende kolon er tilsat i klammer. 
Fasc. 364.II.16

$(\operatorname{Læg} 1)(1 r)$

\author{
Danske Samfund \\ (5 $5^{\text {te }}$ Novbr 1839)
}

Mine Herrer!

Jeg har idag hørt saameget maadeligt Dansk og slet Latin (for jeg var Censor ved Attestats ${ }^{1}$ ) at jeg nødvendig maatte falde i Tanker om hvad her sidst ${ }^{2}$ var paa Bane, nemlig vort Danske Modersmaal, som, det være nyt eller gammelt, er det eneste naturlige Udtryk for vore Tanker og Følelser, og burde altsaa eftergrandskes, forstaaes og bruges meget bedre end det hidtil er skeet af Nogen, for ei at tale om, det Sædvanlige, som er under al Kritik. Det Første, jeg ved denne Leilighed opdagede, var, at vi, jeg selv med, behandlede det vigtige Spørgsmaal om vores nærværende Dansk meget overfladelig, da vi slet ikke gik ind $\mathrm{i}$ hvad det er, som nu skiller vort Modersmaal fra Islandsken, saavelsom fra andre nærbeslægtede Sprog, thi det maae vi nødvendig først besinde os paa, inden vi kan have nogen velgrundet Mening om, enten vort Modersmaal er den Folkestamme, vi tilhøre, eiendommeligt, eller Dansk blot er fordaervet Islandsk ${ }^{3}$, eller et Pluddervælsk og Kiørsammen af Nordisk og Plattydsk. Dette, at Dansk maa være Eet af To, enten en tilsvarende Stammes Tungemaal om ikke fra Babel af, saa dog fra Arildstid, fra de gamle Phønixdage 4 eller blot en Udtværing og Sammenæltning af Naboernes, det blev ikke indskærpet, skiøndt det først $\mathrm{er}^{5}$ den Betragtning, der giver Spørgsmaalet sin Vigtighed for Folkelivet, da det ellers (1v) blot var et af de kuriøse Spørgsmaal, Man maa være lærd for at ændse og ørkesløs for at trættes om. $\mathrm{Nu}$ at bevise enten det Ene eller det Andet, enten at det er et saadant Livsspørgsmaal for os, om Dansk er i Sandhed vort Modersmaal, vort Hjertesprog, eller at Spørgsmaalet maa besvares med Ja, det vil jeg her ingenlunde prøve paa, thi deels er jeg det ikke voxen, og deels maatte Man i det Mindste kiende ligesaameget til de forskiellige Nordiske Sprog og Mundarter som jeg, for at følge og bedømme min Tanke- 
gang. Men Noget kan jeg dog ogsaa her bidrage til disse vigtige Spørgsmaals ${ }^{6}$ Besvarelse ved at lægge $\mathrm{Dem}^{7}$ den paa Hjerte; thi har først vort Hjerte besvaret et Spørgsmaal tilfredstillende for os selv, saa veed De nok $\mathrm{m} . \mathrm{H}^{8}$ at det har en tilsvarende Indflydelse ${ }^{9}$ paa vort Liv og vor Tankegang, enten vi saa kan forklare os tydelig og overbevise Andre om, vi har Ret, eller ikke, medens det paa den anden Side er aldeles frugtesløst, hvor klart vi end med Forstanden kan oprede et Spørgsmaal, hvori Hjertet tager liden eller ingen Deel. Desuden, m.H. jeg gaaer alt saa mærkelig ${ }^{10}$ ned ad Bakke, at jeg neppe faaer Stunder til med mine Nærmeste - end sige med Mange at drøfte hele den særegne Tankegang, der har udviklet sig hos mig under et for det meste udvortes stille og ensomt, men indvortes stærkt bevæget, kæmpende og giærende Liv, saa jeg maatte vel ligesaa godt (2r) først som sidst opgive Fors $\emptyset$ get og indskrænke mig til at vække Medfølelsen, hvor den findes og for Resten anvende mit Efteraar til stedse fuldstændigere og tydeligere paa Papiret at aftegne, hvad der levende rører sig i mig, ${ }^{11}$ og lade denne min Skygge giøre hvad den kan, naar jeg er borte, skiøndt jeg forudseer, det vil være ubetydeligt, hvis mine Landsmænd ei kan lære at finde sig i min Tankegang mens jeg lever. Jeg troede, Timen var kommet, nu da jeg er blevet rolig nok til, naar saa skal være, at tale koldt om hvad der har glødet i mig, og spøgende om hvad der er mit ramme Alvor, og da jeg er blevet klar nok til at kunne skielne det Naturlige i mit Liv og min Tankegang fra det Christelige, og De veed, m. H. det var i dette Samfund jeg haabede at kunne mere levende og virksom end det $i$ Forelæsninger er mueligt, udvikle Dem $^{12}$ min Tankegang om Folkelivet og dets Tarv, der ikke blot speiler sig i Modersmaalet men udtrykker sig deri, saa dermed opstaaer og forgaaer, dermed stiger og synker det; men alle de Fors $\varnothing \mathrm{g}$, jeg hidtil gjorde paa at indlede tilsvarende Samtaler, mislykkedes ganske. At jeg var uskyldig deri, vil jeg ingenlunde paastaae, thi, som jeg fra Først af har sagt $\mathrm{Dem}^{13}$, vi er Allesammen halv fordærvede for Livet, og saa afvante med at samtale naturlig om aandelige Ting, at det er et stort Spørgsmaal, om vi nogensinde lære det igien; men saa (2v) aldeles kunde Forsøgene dog neppe mislykkedes hvis De havde deelt min Følelse af Modersmaalets oprindelige Herlighed og nærværende Armod og Usselhed ${ }^{14}$ i de fleste Munde; thi da 
vilde, da maatte De udspurgt og udfrittet mig baade om Grunden dertil og om Maaden hvorpaa Modersmaalet igien kunde komme til at lyde som fra en Dronningstol ${ }^{15}$ om Alt hvad der findes mellem Himmel og Jord og Alt hvad vi finde $\mathrm{i}$ vor egen Barm; men det har De ingenlunde gjort, men snarere taget mig ilde op, naar jeg i levende Udtryk, der aldrig kunde være for stærke, ophøiede vort Modersmaal over alle fremmede Sprog og beklagede dets Trældom for dem alle, selv for Gienfærdet af den Romerske Troldkvinde. Paa den Maade kan vi ikke tale sammen, thi jeg kan ikke, for at vinde Deres Bifald, opgive mit Øiemed, og jeg har i min Alder ikke Stunder til at fare med Sneglen, saa naar De ikke deler denne min Grundfølelse[:] "Dansk fremfor alt andet i denne Verden, Dansk i Tankegang som Modersmaalet er, og dette Modersmaal i Ære, hvor vi boe, over alle Tungemaal under Himmelen, dette Modersmaal, som er vort Hjertes Skat, være vore Tankers Dronning, som vi vil følge i Alt hvad ei er Synd, dette Modersmaal vor ${ }^{16}$ naturlige Livsfylde, vi stedse vil stræbe kiærligere at favne, bedre at forstaae og klarere at fremstille["], naar De ikke deler den Grundfølelse, saa Latin og

$(\operatorname{Læg} 2)(3 r)$

Græsk, al Verdens Skolemesterskab og Videnskabelighed maa underordne sig og nøies med, hvad Dansken kan taale og Dansken vil unde, da nytter det ikke, vi taler sammen om nogetsomhelst Naturligt og Folkeligt, thi derfra lader jeg mig bestemt ikke rokke end sige omvende, og jeg har i mine Dage spildt saamegen Tid paa Trætteri med grundforskiellige Naturer, at jeg har ikke Raad til mere. Da jeg imidlertid tør forudsætte, at hvor sære og stødende end mange af mine Paastande om den ægte Danskhed og naturlig Dannelse i skarpeste Modsætning til Latiniteten og al den Unatur, som dermed følger, hvor sære og stødende, siger jeg, De end har fundet mine Paastande, De dog ikke ringeagter enten de Kræfter, der hos mig giennem en heel Menneskealder var i levende og kiendelig Bevægelse, eller Menneske-Maalet, jeg stræbde til, eller den Grad af Dannelse 
og Magt med Modersmaalet, jeg vandt, da jeg tør forudsætte det, saa tør jeg ogsaa haabe, De endnu et Øieblik laaner mig Øre, mens jeg fortæller Dem, hvordan det i Levnetsløbet er gaaet mig med Danskhed og Modersmaal, for at De kan see, mine Tanker derom er ikke Noget, enten De eller jeg selv kan skille fra, men at Alt hvad jeg har været og Alt hvad jeg er blevet eller kan blive, det er jeg blevet med dem. (3v) Jeg er en Sællandsfar ${ }^{17}$ igiennem mange Ledd, men voxde op i Jylland ${ }^{18}$ fra jeg var 9 Aar, til jeg blev 17, og omfavnede med lige Kiærlighed fra Barndommen de to mest forskiellige Mundarter af Modersmaalet, og denne blinde Kiærlighed, næret ved tidlig Læsning af Danske Bøger ${ }^{19}$, som huede mig, og af sig selv udvidet til alt ægte Dansk, det er min Grundfølelse, der vel i den sorte Skole ${ }^{20}$ tabde det meste af sit Liv, men tabde sig dog ingenlunde deri, saa jeg sværmede ligesaavel for Dansk og Danskhed, da jeg gik ud af Skolen, som da jeg gik ind i den, kun koldere og mere luftig. Vel snakkede jeg rask Latin i Studenter-Dagene, fordi mig syndes, de blev derved lidt mindre kiedsommelige, men jeg spyttede det saavidt mueligt ud med Attestatsen $^{21}$, og uagtet min Tunge aldrig er blevet rigtig reen igien, stræbde jeg dog omhyggelig at rense den, og modstod al Fristelse til at tale Tydsk, uagtet jeg levede flere Aar i et Huus ${ }^{22}$ og en Kreds, hvor det taltes flydende og Dansk var kun Tjenersproget. Da, netop for en Menneske-Alder siden, blev jeg Forfatter, saa, om jeg end vilde dølge det, gaaer der Syn for Sagn, at jeg havde forgabet mig i Islandsken, som om den var Nordens alma mater ${ }^{23}$, og Dansken, som den nu taltes, om ingen Slegfred-Afkom ${ }^{24}$, saa dog en vanartet Datter, der maatte optugtes paany med Sagasproget fra Island, og skiøndt den gamle Kiærlighed ikke rustede, fattedes den dog Høiagtelsen, som Danmarks (4r) høihjertede Dronning aldrig vil savne hos de Tilbedere, hun skal tilsmile. Saavidt jeg kan skiønne, var imidlertid Hovedaarsagen til min Udsvævelse ${ }^{25}$, den giennem Aarhundrede indgroede Fordom, at Dansk og Norsk var i alle Maader en i Modersliv sammenvoxet Tvilling, der ei kunde adskilles uden fælles Død, thi først da den udvortes Skilsmisse ${ }^{26}$ klarlig havde beviist det Modsatte, begyndte Tvilling-Begrebet, trods al Modsigelse, ogsaa indvortes at adskille sig og jeg glemmer aldrig det Øieblik, da jeg atter sank i vor Moders 
Arme, følde med ubeskrivelig Glæde, at jeg havde et Modersmaal, som hverken var Norsk eller Islandsk eller noget andet end Dansk. Det var 1816, jeg oplevede denne Vending ikke blot i min Stil og min Sproggrandskning, men i hele mit Naturliv og det var ved Læsningen af den gamle Danske Rimkrønike ${ }^{27}$ Naturen gik over Optugtelsen, saa det maa ikke forundre Dem, om jeg har tilskrevet ${ }^{28}$ den lille mageløse Bog hvad ingen Bog formaaer, thi i Hjertets Anliggender kan vi sjælden skielne den virkelige Aarsag fra den nærmeste Anledning, og her var det næsten umueligt, da Rimkrøniken er saa aldeles skrevet ud af Danmarks Hjerte, som ingen Anden, og derfor i sin Stil fra først til sidst saa ægte Dansk, at kunde Man lære at ${ }^{29}$ kiende Tungemaal af Bøger, da maatte det ene være af Saadanne. Over tyve Aar er forløbne siden dette Giennembrud, jeg har syslet meer med fremmede $\operatorname{Sprog}^{30}$ end nogensinde før, jeg har selv lært at (4v) tale et fremmed Sprog ${ }^{31}$ taalelig og ikke ubetydelig udvidet mit Bekiendskab med andre Nordiske Sprog, men jeg har intet Øieblik vaklet i min Overbeviisning, at vort Dansk er fra Arildstid Danmarks Tungemaal, og aldrig holdt op at beklage, at de der kalde sig Oplyste og Dannede iblandt os, tale deres Modersmaal som et fremmed Sprog, om hvis Rigdom ${ }^{32}$ Dybde og Deilighed, de har ikke mindste Begreb. Mine Fordanskninger ${ }^{33}$ af Saxes og Snorres Krøniker og af Bjovulfs Drape var de første kiendelige Frugter af min egen Fordanskning, og vil Man see Forskiellen mellem Dansk og Islandsk, tænker jeg, den vil være kiendelig nok, naar Man sammenligner min Oversættelse af Snorre, med den, der nys er udkommet i Norge ${ }^{34}$, som skal være ordret; thi mellem nærbeslægtede Sprog skal Man ikke nær saameget see paa Ordene, som paa deres Brug, paa Ordføining, Vendinger, Ordsprog og Talemaader, som er Livet og Sjælen deri. Ja, Liv og Sjael, her har vi, om jeg ikke tager feil en af Modersmaalets utallige Eiendommeligheder, ikke fordi det jo ${ }^{35}$ har Ordene tilfælles baade med Tydsk og Islandsk, men fordi det forbinder og bruger dem paa en egen Maade, saa det siges kun paa Dansk at være En med Liv og Sjæl hengiven, ligesom at giøre noget med Liv og Lyst [manuskriptet slutter her uden punktum, idet der på papiret dog er plads til endnu ca. fire linjer] 
Fasc. 364.II.17

$(1 \mathrm{r})$

Danske Samfund

(5 $5^{\text {te }}$ Novbr 1839)

\section{Mine Herrer!}

Vi talde sidst ${ }^{36}$ endeel om Modersmaalet og dets Bestandighed, og trængde jeg til at mindes om denne Materies Vigtighed for det Danske Samfund baade her og over hele Riget, da kunde det vel være Mindelse nok at jeg idag har maattet høre endeel daarlig Dansk og slet Latin, men en endnu stærkere var det dog hvad jeg forleden Dag saae af Folkebladet ${ }^{37}$, at en Holstener i Zeitung für die elegante Welt med stor Frimodighed paastaaer, at det Danske Sprog ei blot i Slesvig men ogsaa hos os ligger i sidste Aandedræt, og kan umuelig reddes fra samme sørgelige Helsot $^{38}$, som det Plattydske, da Høitydsken ogsaa ved Belt og Sund har plantet sit seierrige Ørnebanner, som Løverne maae synke i Jorden for hvormeget end Hjerterne bløde. Det var vist nok ikke Plattydske men høitydske Pral, der forskrækkede mig, meget meer morede det mig et Øieblik kostelig, at enhver dannet Mand hos os, efter hans Paastand, kunde tale ligesaagodt Tydsk som Dansk, saa naar han ikke vilde være det bekiendt, var det kun en Finte, og det maatte nødvendig more mig, da jeg har en god Samvittighed for, det er ingen Finte af mig, naar jeg radbrækker Tydsken. Men hvad der snart gjorde mig alvorlig

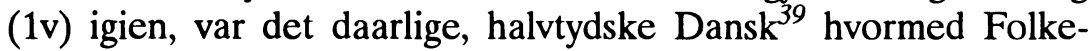
bladet tog til Gienmæle, thi ved at betragte det, maatte jeg sige til mig selv, at det var dog ikke slettere end det Man sædvanlig seer i vore Bøger og hører i de saakaldte Dannedes Mund, og at kunde det ikke blive bedre med os, kunde vort Modersmaal ikke anderledes giøre sig giældende, da maatte Tydskernes Spaadom virkelig gaae i Opfyldelse, og da tabde Verden heller intet derved. Medens det nemlig stod lyslevende for mig, at havde mine Landsmænd kun samme Følelse for Modersmaalet, dets Ret til at herske i vor Tankegang som i vor Mund og dets inderlige Deilighed, Havfruedronningen ${ }^{40}$ værdig, da kunde vi lee 
ad alle høitydske Bannere og plattydske Ulykkesfugle, saa maatte jeg paa den anden Side tilstaae, at kun saare Faa syndes at dele denne min Danske Følelse, og at det selv var mig tvivlsomt, hvorvidt den herskede i dette Samfund, hvori den dog maa være Livet og Sjælen, hvis det skal svare til sit Navn og ei være et af de mange dødfødte Børn, vor Moder havde ventet Trøst og Glæde af. $\mathrm{Nu}$, det Sidste var vel kun en Fristelse til Mistvivl, som snart vil overvindes, da det vilde være aldeles ubegribeligt [manuskriptet slutter her nederst på bladet]

\section{Noter:}

1 Attestats, teologisk embedseksamen. Mens professorerne tidligere fungerede både som eksaminatorer og censorer, blev det fra 1788 bestemt, at to udefrakommende præster, en hofpræst og en københavnsk sognepræst, skulle votere om karaktererne. Ved resolution af 12. maj 1830 udvidedes kredsen til at omfatte residerende kapellaner $\mathrm{i}$ hovedstaden og præsten ved Vartov Hospital. Se i øvrigt Bjørn Kornerup og K.E.Bugge i Kirkehistoriske Samlinger 1960, s. 98-113.

2 sidst, mødet 29. oktober 1839, hvortil intet oplæg af Grundtvig er bevaret.

3 fordarvet Islandsk, Rasmus Rask (1787-1832), periodens førende sprogforsker, anså i størstedelen af sit forfatterskab islandsk for at være danskens modersprog.

4 Phønixdage, Grundtvigs oplæg på mødet 22. oktober 1839 beskæftiger sig netop med Føniksfuglen, om hvis levealder det hedder: "Det er hans Liv i tusind Aar" (Grundtvig-arkivet, fasc. 364.II.64 1v).

5

er, ordet mangler i manuskriptet.

6 Spørgsmaals, manuskriptet har: "Spørgsmaalets".

7 Dem, manuskriptet har "dem".

8 m.H., "mine Herrer"

9 Indflydelse, manuskriptet har: "Indflydelsen".

10 maerkelig, kendeligt. 
$11 \mathrm{mig}$, herefter har manuskriptet følgende overstregede sætning: "i det Haab, at denne Tegning vil findes tilstrækkelig".

12 Dem, manuskriptet har: "dem".

13 Dem, manuskriptet har: "dem".

14 Usselhed, manuskriptet har: "Usselsed", men i en slettet version tre ord tidligere: "Usselhed".

15 Dronningstol, Dronningestolen på Møns klint, der til 1868 var af betydelig højde, opfatter Grundtvig som Frejas trone, men han bruger også ordet om den danske dronningetrone, sæde for Frederik 6.s Marie og Christian 8.s Caroline Amalie. Se i øvrigt Helge Toldberg: Grundtvigs symbolverden, 1950, s. $163-165$.

16 vor, manuskriptet har: "vort".

17 Sallandsfar, sjællænder.

18 Jylland, Grundtvig opholdt sig i Tyregodlund præstegård i Tyregod ved Vejle fra efteråret 1792 til september 1798.

19 Danske Bøger, bl.a. de gamle almuebøger om Karl den Store og Holger Danske samt P.F. Suhms, P.A. Heibergs og K.L. Rahbeks skrifter fra det 18. århundredes sidste del.

20 den sorte Skole, Aarhus katedralskole, hvor Grundtvig var elev fra oktober 1798 til september 1800 .

21 Attestatsen, Grundtvig bestod teologisk embedseksamen 25. oktober 1803.

22 et Huus, herregården Egeløkke på Langeland, hvor Grundtvig var huslærer fra omkring 1. april 1805 til slutningen af april 1808.

23 alma mater, (foster)moder.

24 Slegfred-Afkom, barn født uden for ægteskab.

25 Udsvaevelse, urimelig eller yderliggående mening.

26 Skilsmisse, ved freden i Kiel 1814 blev Norge udskilt af det danske rige efter mere end 400 års forening. 
27 Rimkrønike, den danske Rimkrønike fra senmiddelalderen trykkes som den første danske bog på dansk i 1495 med nye oplag frem til 1613; C. Molbech genudgav den i 1825. Grundtvig begyndte så småt sine studier i Rimkrøniken i sommeren 1814, offentliggjorde uddrag af den i Danne-Virke, I, 1816, og anmeldte udførligt Molbechs udgave i Nyt Aftenblad 1826. I 1834 arbejdede han på en aldrig færdiggjort moderne bearbejdelse og fortsættelse, hvoraf prøver tryktes med indledning i Den Nordiske Kirke-Tidende 17. august dette år.

28 tilskrevet, tillagt, nemlig i ovennæunte indledning fra 1834, hvor Grundtvig erklærer, at Rimkrøniken kan vække den danske folkeånd og fædrelandskærlighed og således blive en sand fædrelandskatekismus.

29 at, manuskriptet har: "et", som Grundtvig har glemt at rette i konsekvens af en her udeladt rettelse.

30 fremmede Sprog, 1812-14 tænkte Grundtvig på at blive tysk forfatter og skrev et par korte tekster på tysk; andre sprog er nævnt i de følgende noter.

31 et fremmed Sprog, engelsk, som Grundtvig fik lejlighed til at bruge på sine tre sommerrejser til England 1829-31. Ifølge oplæg til mødet i Danske Samfund 31. august 1841 fungerede han som tolk, da den britiske fængselsreformator, kvækeren Mrs. Elizabeth Fry ugen før besøgte København for at bese Stokhuset og Børnehuset (Grundtvig-arkivet, fasc. 364.II.60).

32 Rigdom, ordet er indsat i marginen.

33 Fordanskninger, oversættelserne af Saxo og Snorre udkom i tre bind hver 1818-23 (trykår 1822), gendigtningen af det angelsaksiske Beowulf-kvad i 1820.

34 udkommet i Norge, Snorre Sturlesons norske Kongers Sagaer, oversat af Jacob Aall, I-III, Christiania, 1838-39.

35 jo, (efter nægtende forsætning) ikke.

36 sidst, se note 2.

37 Folkebladet, ugeskriftet Dansk Folkeblad, udgivet (nærmest i avisudstyr) af Selskabet for Trykkefrihedens rette Brug, bragte fredag 1. november $1839 \mathrm{i}$ No. 36-37, s. 141-148, en artikel, betitlet "Evnen er ikke altid som Villien", med det indhold, Grundtvig kort refererer. Den opgives at stamme fra septembernummeret af Zeitschrift für die elegante Welt.

38 Helsot, sygdom til døden. 
39 det daarlige, halvtydske Dansk, den lange tospaltet opsatte artikel har sekssyv germanismer som: "Det kan man dog engang kalde at tale!" (das heisst doch einmal reden), "opdækkede" (= bragte for dagen, aufgedeckt), "Gebeter", "hendrage" (=tiltrække, hinziehen), "komme .. for Touren" (= blive ens tur til, an die Reihe kommen), "vundet megen Jordbund" (Boden gewonnen). Ellers forekommer dens sprog nu ikke en moderne læser påfaldende udansk eller halvtysk.

40 Havfruedronningen, et af Grundtvigs billeder for den danske folkeånd. Se i øvrigt Helge Toldberg: Grundtvigs symbolverden, 1950, s. 187-201. 